\title{
СУДОВИЙ ЗАХИСТ ПРАВ ЛЮДИНИ
}

\author{
ЖАРОВСЬКА Ірина Мирославівна - доктор юридичних наук, професор \\ кафедри теорії та філософії права, Інститут права та психології Національного \\ університету «Львівська політехніка» \\ ORCID ID : https://orcid.org/0000-0003-3821-8120 \\ ОРТИНСЬКА Наталія Володимирівна - доктор юридичних наук, доцент \\ кафедри політології і міжнародних відносин, Інститут гуманітарних та соціальних \\ наук Національного університету «Львівська політехніка» \\ ORCID ID : https://orcid.org/0000-0002-5061-5340 \\ УДК 340.12:342.7:[347.925:342.56] \\ DOI:10.32782/NP.2020.2.1
}

\begin{abstract}
Права человека всть той особой чзенностью, что человечество приобретало веками в борьбе за свое должное существование. Важность их защить возлагается на государство, тем самыл ставит его на высшую ступень задач которьие на нее возложеньл. Безусловно, что судебная система играет одну из важнейших ролей в этом процессе деятельность которой требует тех условий которье должнь отвечать выссоким стандартам правового государства.

Ключевъе слова: права человека, судебная защита, принщипь права, основнье права.
\end{abstract}

Постановка проблеми

Права людини є особливим надбанням людства, що роками викристалізовувались та удосконалювались у зв'язку із постійним прагненням людини убезпечити своє належне існування. Кожне із поколінь прав людини має свою надзвичайну цінність, оскільки залишається актуальним у сьогоднішних глобалізаційних і трансформаційних умовах, що лише надає їм більшої вагомості для доктрини та практики. Дотримання прав людини у державі став у сьогоденні певним індикатором ії розвитку як у правовому полі, так і загалом, що підкреслює важливість цього інституту у світовому масштабі. Конституція України визначає, що «людина, iii життя і здоров'я, честь і гідність, недоторканність і безпека визнаються в Україні найвищою соціальною цінністю» [1], що підкреслює людиноцентриську тенденцію, що формується і в нашій державі. Основний закон декларував широкий каталог прав людини, що потребують належного дотримання та захисту, оскільки без дієвого механізму їхньої реалізації вони видаються ілюзорними, а у сьогоднішних умовах формування нашої держави як правової це відіграє ключову роль.

\section{Стан дослідження}

Дослідження захисту прав та свобод людини займалася досить велика кількість вітчизняних та зарубіжних науковців, такі як: В. Авер'янов, О. Батанов, А. Георгіца, С. Качанов, М. Козюбра, В. Погорілко, П. Рабінович, Ю. Размєтаєва, О. Скрипнюк, С. Шевчук, Ю. Шемшученко та ін.

Незважаючи на велику кількість праць у досліджуваній тематиці цілісної характеристики теоретичних аспектів судового захисту прав людини, ми не виявили.

Метою цієї наукової статті $€$ теоретичний аналіз основоположних та засадничих принципів захисту прав та свобод людини.

Належний захист прав людини можливий лише у випадку створення державою належних для цього умов, у яких суд буде тим незалежним арбітром, що покликаний охороняти та забезпечувати права людини. Важливість цього підкреслюється також і на шляху нашої держави до становлення як правової.

Аналізуючи інститут забезпечення прав і свобод людини, Я. Троян висвітлює їх особливості, зазначаючи, що «забезпечення 


\section{Теорія, історія держави і права, конституційне право}

прав і свобод людини - це створення відповідних умов для здійснення прав і свобод людини, що має три цілеспрямовані сфери державної діяльності: 1) сприяння реалізації прав і свобод людини (шляхом позитивного впливу на формування їх загальносоціальних та юридичних гарантій); 2) охорона прав і свобод людини (створення системи заходів, спрямованих на попередження правопорушень, усунення причин, що їх спричиняють); 3) захист прав і свобод людини у разі їх порушення (створення певної системи засобів та факторів, застосування яких пов'язане 3 наявністю ситуації, за якої порушуються права, та відновлення порушеного права)» [2, с. 213]. Погоджуючись 3 висловлюваннями автора, мусимо констатувати, що першочерговим завданням держави є саме створення умов, у яких, окрім сприяння реалізації, буде ефективне попередження правопорушень у сфері прав та свобод людини. Демонстративним прикладом цьому є налагодження роботи всіх органів державної влади, що неупереджено діють у відповідності до декларованих норм законодавства. Недоліки, що сьогодні все ще існують в нашій державі щодо дотримання людських прав, можливо прослідкувати у зверненнях громадян України у Европейський суд 3 прав людини для акценту на ті проблемні аспекти, які потребують негайного вирішення. Тому превенційна функція щодо порушення прав людини повинна бути тим напрямком, якому сучасна держава повинна слідувати. Варто також зауважити, що у сьогоденні можливо підкреслити значний прогрес у цьому питанні, оскільки більшість органів державної влади пройшла певну реформацію, що тим самим покращила ефективність та результативність їхньої роботи.

Суд є тим основним органом, що покликаний забезпечувати реалізацію прав людини, Конвенція про захист прав людини і основоположних свобод у ст. 6 визначає, що «кожен має право на справедливий і публічний розгляд його справи упродовж розумного строку незалежним і безстороннім судом, встановленим законом, який вирішить спір щодо його прав та обов'язків цивільного характеру або встановить об- грунтованість будь-якого висунутого проти нього кримінального обвинувачення» [3].У сучасному суспільстві органи судової влади мають величезне значення для розвитку нашої держави та формування їхнього позитивного сприйняття, оскільки при існуванні незалежних судів можливо говорити про правовий захист людини. Саме тому одним iз основних завдань держави є створення всіх необхідних умов для ефективної та неупередженої роботи судової гілки влади, що i $\epsilon$ запорукою формування правової держави із високим дотриманням прав людини на належному рівні. Право людини на судовий захист декларовано також ст. 55 Конституції України: «кожному гарантується право на оскарження в суді рішень, дій чи бездіяльності органів державної влади, органів місцевого самоврядування, посадових і службових осіб» [1].

Особливого значення судові органи відіграють у поступальному руху України в євроінтеграційних процесах, що встановлюють певні вимоги до їхньої діяльності, що є однією із причин які стимулюють нашу державу постійно удосконалювати всі процеси правосуддя. Існує нагальна необхідність приведення вітчизняного законодавства як європейських, так і міжнародних стандартів.

Аналізуючи питання судових гарантій прав людини, С. Качанов на рівні дисертаційного дослідження влучно зазначає, що така реалізація можлива лише у випадку виконання державою позитивних та негативних зобов'язань, до негативних відносячи обов'язок не втручатися у сам процес правосуддя, у позивному аспекті розуміється створення умов для діяльності неупереджених та незалежних судів, а також безперешкодні умови доступу до суду, що не будуть обтяжені як економічними, так і юридичними обмеженнями та забезпечення виконання судових рішень [4, с. 190-191].

Справедливий суд є тим ідеалом, що прагне досягнути кожна правова держава, що сповідує основні принципи, що століттями формувалися у правовому полі та мають у сьогоденні аксіологічне значення.Н. Грень влучно зазначає, що «право людини на справедливий суд є невід'ємним, од- 
ним із найвагоміших прав людини, оскільки через його реалізацію відбувається поновлення тих прав і свобод, які були порушені. Від функціонування права на справедливий суд залежить система права загалом, тому що воно є гарантією захисту всіх інших прав. Досліджуване право передбачає втілення всіх морально-ціннісних надбань людства, оскільки йдеться про правовий принцип пріоритету верховенства права, справедливості, рівності та свободи» [5, с. 12].

Важливою особливістю також у сучасності є довіра громадськості до судової гілки влади, що відображає всю парадигму побудови судової системи та ії діяльності, саме тому необхідність вбачається нарощувати їі авторитет за допомогою власне справедливості та неупередженості, що є тими аксіоматичними підвалинами, які повинні формувати переконання у можливості захисту своїх прав у ньому. Звичайно, що формування авторитету суду лежить на плечах самих суддів, що повинні демонструвати високі професійні навики і при цьому бути об'єктивними та справедливими, слідуючи букві та духу закону, що зможе поступово змінити сьогоднішні низькі показники довіри громадськості до судової системи, що разюче відрізняється від країн Заходу, що досягли стабільних результатів у цьому питанні.

Д. Аблязов, досліджуючи судовий захист прав людини і громадянина, влучно зауважує, що «розширення сфери судового втручання і процедури усунення наслідків порушення прав і свобод громадян можна назвати критерієм демократизації суспільства, підтвердженням значимості в ньому загальнолюдських ідеалів, підпорядкування здоровому глузду і моральним цінностям. Основні засади судової влади - самостійність і незалежність їі статусу - перетворює судову форму захисту прав людини на найбільш правильне, надійне і зрозуміле ії джерело» $[6$, с. 78$]$.

Доктрину практики захисту прав людини предметно досліджувала Ю. Разметяєва, наводячи основні принципи, що існують у європейському праві, зазначаючи принцип справедливості, що розуміється як неупереджене ставлення до носіїв прав при їхньому захисті та реалізації і неупередженості розгляду справ. Принцип пропорційності авторка тісно пов'язуе із принципом справедливості, що характерно для всіх принципів права, визначаючи його особливості у балансі, співмірності та доречності. У принципі рівності виявляється у рівності всіх перед законом, тобто однаковий доступ до прав та можливостей, що закладений у досліджуваному інституті. Принцип свободи втілюеться в автономії особи різноманітності і толерантності. У принципі гуманізму вбачається сприйняття людини як особи та особистості, що переплетений із i вільним розвитком і дотриманням певного рівня життя і добробуту, також авторка виділяе принцип добросовісності, розумності та правової визначеності [7. с. 116-119].У процесі судового захисту важливим видається постійна взаємодія всіх принципів, що повинні взаємодіяти один з одним, оскільки ізольоване застосування одного із них не дозволить досягнути всіх цілей, що ставить перед собою суд у питанні захисту прав та свобод людини. Отже, на державу ставиться важливе завдання створення всіх належних умов для реалізації цих принципів задля ефективної роботи судової системи. При наявності справедливого та належного суду в нашій державі поступово зменшиться і звернення наших громадян до Европейського суду з прав людини, що буде тим позитивним індикатором змін, до якого прагне кожна розвинута держава світу у ії становленні як правової. Як уже зазначалось, для втілення в життя цих ключових елементів необхідним видається наявність високого авторитету і самих суддів, що під час виконання своїх професійних обов'язків будуть демонструвати повагу до всіх принципів та цінностей, що декларовані в законодавстві та гарантуються Основним законом, що підкреслюе їхню важливість.

\section{Висновки}

Інститут прав людини 6 особливо ціннісним у сьогоднішних трансформаційних реаліях та в період становлення нашої держави як правової, а їхнє належне дотримання свідчить про розвиток як самої держави, так і їі правових інституцій. У сьогоденні 


\section{Теорія, історія держави і права, конституційне право}

\section{АНОТАЦІЯ}

Права людини є тою особливою цуінністю, що людство набувало століттями у боротьбі за своє належн існування. Важливість їхнього захисту покладається на державу, шоо тим самим ставить його на найвищий шабель завдань які на неї покладені. Беззаперечно, що судова система відіграє одну з найважливіших ролей у иъому процесі діяльність якої потребує тих умов, що повинні відповідати високим стандартам правової держави.

Ключові слова: права людини, судовий захист, принципи права, основоположні права.

необхідність є у постійній взаємодії всіх принципів права для належного та справедливого судового процесу, задля якісного та об'ємного захисту порушених прав людини, а в той час судді повинні відповідати всім високим стандартам, що існують задля підвищення довіри громадськості, що є вкрай важливою у сьогоднішних трансформаційних умовах.

\section{Література}

1. Конституція України: Закон України від 28.06.1996 № 254к/96-BP. URL: https:// zakon.rada.gov.ua/laws/show/254к/96-вр

2. Троян Я. Інститут забезпечення конституційних прав i свобод: поняття, основні ознаки. Підприємництво господарство $i$ право. № 6. 2018. C. 210-214. URL: http:// www.pgp-journal.kiev.ua/archive/2018/6/39. pdf

3. Конвенція про захист прав ^юдини і основоположних свобод від 04.11. 1950. URL: https://zakon.rada.gov.ua/laws/ card/995 004

4. Качанов E. О. Судові гарантії прав людини: дис. ...канд. юрид. наук : 12.00.01. Харків, 2018. 214 с.

5. рень Н.М. Реалізація права людини на справедливий суд шляхом процедури присудової медіації: теоретико-правове дослідження : автореф. ... канд. юрид. наук: 12.00.01. Аьвів, 2017. 21 с.
6. Аблязов Д. Е. Судовий захист прав людини і громадянина. Право і Безпека. 2012. №1. С. 75-79.

7. Разметаєва Ю. С. Доктрина та практика захисту прав людини. Навчальний посібник. Київ, 2018. 362 с. URL: https:// nlu.edu.ua/wp-content/uploads/2019/08/PhD1-Доктрина-та-практика-системи-захиступрав-людини.pdf

\section{JUDICIAL PROTECTION OF HUMAN RIGHTS}

Human rights are a special value that humanity has acquired over the centuries in the struggle for its proper existence. The importance of their protection rests with the state, which puts it at the highest level of the tasks assigned to it. There is no doubt that the judiciary plays one of the most important roles in this process, the activities of which require the conditions that must meet the high standards of the rule of law. Adequate protection of human rights is possible only if the state creates appropriate conditions in which the court will be the independent arbitrator called to protect and ensure human rights. The importance of this is also emphasized on the way of our state to becoming a legal state.

An important feature of modern times is the public's trust in the judicial branch of government, which reflects the whole paradigm of building the judiciary and its activities, which is why it is necessary to increase its authority through justice and impartiality, which are the axiomatic foundations that should form beliefs of the possibility of protecting their rights in it. Of course, the formation of the authority of the court lies on the shoulders of the judges themselves, who must demonstrate high professional skills and at the same time be objective and fair following the letter and spirit of the law, which can gradually change today's low levels of public confidence in the judiciary, which is strikingly different from Western countries that have achieved stable results in this regard.

Keywords: human rights, judicial protection, principles of law, fundamental rights. 